\title{
Milk and fat production of crossbred Holstein-Gir cows (Bos taurus taurus-Bos taurus indicus) in the Agreste region of the Brazilian state of Pernambuco
}

\author{
Severino B.P. Barbosa ${ }^{1}$, Ricardo P. Ramalho ${ }^{1}$, Humberto G. Monardes ${ }^{2}$, Flávio M. Dias ${ }^{3}$, \\ Djalma C. dos Santos ${ }^{3}$ and Ângela M.V. Batista ${ }^{1}$ \\ ${ }^{I}$ Departamento de Zootecnia, Universidade Federal Rural de Pernambuco, Recife, PE, Brazil. \\ ${ }^{2}$ Department of Animal Science, McGill University, QC, Canada. \\ ${ }^{3}$ Empresa Pernambucana de Pesquisa Agropecuária, Recife, PE, Brazil.
}

\begin{abstract}
The productive performance of four Holstein-Gir genetic groups $(1 / 2 \mathrm{H}, 1 / 4 \mathrm{H}, 5 / 8 \mathrm{H}, 5 / 8 \mathrm{Hinter}$ se $)$ and the effects of non-genetic factors on production traits was evaluated using a data set of 7,951 test-day samples collected between January 1980 and December 1999 from the Arcoverde Experimental Station in the Brazilian state of Pernambuco (Empresa Pernambucana de Pesquisa Agropecuária). The statistical model included the fixed effects of calving year (1980 to 1999) and month (January to December), genetic group of the cow, age at months of calving (33 to 190) and days in milk at each test-day. Random effects were sire, cow and residual with test-days treated as repeated records within each cow within each lactation. For the four genetic groups the milk yield (MY) means were $1 / 2 \mathrm{H}=8.61 \mathrm{~kg} \pm 1.16 \mathrm{~kg}, 1 / 4 \mathrm{H}=5.34 \mathrm{~kg} \pm 0.46 \mathrm{~kg}, 5 / 8 \mathrm{H}=7.42 \mathrm{~kg} \pm 0.39 \mathrm{~kg}$ and $5 / 8 \mathrm{H}$ inter se $=5.76 \mathrm{~kg} \pm 0.46 \mathrm{~kg}$; the fat yield $(F Y)$ means were $1 / 2 \mathrm{H}=0.375 \mathrm{~kg} \pm 0.052 \mathrm{~kg}, 1 / 4 \mathrm{H}=0.231 \mathrm{~kg} \pm 0.026 \mathrm{~kg}, 5 / 8 \mathrm{H}=0.299 \mathrm{~kg} \pm 0.025 \mathrm{~kg}$ and $5 / 8 \mathrm{H}$ inter se $=0.231 \mathrm{~kg} \pm 0.026 \mathrm{~kg}$; and the fat percentage $(\mathrm{FP})$ means were $1 / 2 \mathrm{H}=4.45 \mathrm{~kg} \pm 0.29 \%$, $1 / 4 \mathrm{H}=4.08 \mathrm{~kg} \pm 0.12 \%, 5 / 8 \mathrm{H}=3.87 \mathrm{~kg} \pm 0.10 \%$ and $5 / 8 \mathrm{Hinter}$ se $=3.89 \mathrm{~kg} \pm 0.12 \%$. Phenotypic correlations between tests were $\mathrm{MY}=0.97, \mathrm{FY}=0.94$ and $\mathrm{FP}=0.98$. The best productive performance was for the $1 / 2 \mathrm{H}$ group, followed by the $5 / 8 \mathrm{H}$ group. The performance of the synthetic group was substantially below the performance of the $5 / 8 \mathrm{H}$ group.
\end{abstract}

Key words: genetic groups, epistasis, genetics groups, recombination, repeated measures, test-day.

Received: March 21, 2007; Accepted: September 18, 2007.

\section{Introduction}

Brazil produced almost 25 billion liters of milk in 2005 , representing an increase of approximately $27 \%$ since 2000. In the state of Pernambuco, milk production is around 397 million liters (IBGE, 2004), placing the state as the second largest producer in the Northeast region of Brazil. Dairy herds are composed of a large variety of crossed cattle managed extensively, with various studies suggesting the use of crossbred cattle under tropical conditions for milk production (Madgwick and Goddard, 1989; Ahlborn-Breier and Honenboken, 1991; Touchberry, 1992; Zarnecki et al., 1993) yet other studies supporting the use of purebred European cattle in the same regions (Swan and Kinghorn, 1992; Simpson and Conrad, 1993; McDowell et al., 1996). It would appear that the particular environmental

Send correspondence to Severino Benone Paes Barbosa. Rua Afonso Celso 66, Ap. 902, Bairro Parnamirim, 52060-110 Recife, PE, Brazil. E-mail: sbarbosa@dz.ufrpe.br. conditions may dictate which genetic solution is most appropriate.

In the 1980s an agricultural research organization (Empresa Pernambucana de Pesquisa Agropecuária) in Pernambuco state in Northeast Brazil initiated a crossbreeding program using reciprocal or alternate crosses to produce crossbred Bos taurus taurus Holstein $(\mathrm{H})+$ Bos taurus indicus Gir $(\mathrm{G})$ cattle. The objective of the study described in this paper was to evaluate the performance of the four different genetic groups $(1 / 2 \mathrm{H}, 1 / 4 \mathrm{H}, 5 / 8 \mathrm{H}, 5 / 8 \mathrm{Hinter}$ se) participating in the process of producing $5 / 8 \mathrm{H}+3 / 8 \mathrm{G}$ synthetic Holstein-Gir cattle.

\section{Material and Methods}

In this study, 8,252 test-day milk yields and corresponding fat content values were obtained between 1980 and 1999 from 1,212 lactations of four Holstein-Gir genetic groups $(1 / 2 \mathrm{H}, 1 / 4 \mathrm{H}, 5 / 8 \mathrm{H}, 5 / 8 \mathrm{Hinter}$ se). These data came 
from a herd developed at the Arcoverde Experimental Station of the Pernambuco Institute of Livestock Research (Empresa Pernambucana de Pesquisa Agropecuária (IPA), Recife, Pernambuco, Brazil) with the objective of producing a $5 / 8 \mathrm{H}+3 / 8 \mathrm{G}$ synthetic Holstein and Gir crossbred using a rotational crossing scheme. The experimental station, used exclusively for milk production, is located in the prefecture of Arcoverde in the Brazilian state of Pernambuco in an area known to as the "drought polygon" (polígono das secas) at $8^{\circ} 25^{\prime} 00^{\prime \prime} \mathrm{S} 37^{\circ} 03^{\prime} 15^{\prime \prime} \mathrm{W}$ at an altitude of 664 meters and with an average yearly precipitation of $716.8 \mathrm{~mm}$. The region has two well-defined seasons, a dry season normally lasting from September to February and a rainy season extending from March to August. In the dry season, cattle are stabled and managed using a semi-intensive system with a dietary base of spineless cactus (Opuntia ficus) and sorghum (Sorghum bicolor (l.) Moench) silage. In the rainy season, cows are placed in a specific microclimatic area of the station called Serra da Vara, where they are raised on Pangola (Digitaria decumbens) and Signal (Brachiaria decumbens) grasses. Cows producing over $6 \mathrm{~kg}$ of milk per day received $2 \mathrm{~kg}$ of commercial feed with $18 \%$ to $22 \%$ (dry matter basis) crude protein. Mineral salt was administered ad libitum in separate troughs during the dry and rainy periods.

Breeding took place throughout the year, by either artificial insemination or controlled natural service. Milking was performed manually twice a day, the first at 5:30 h, and the second at 15:30 h. The calves were separated from their mothers a week after birth. At each milking, the calves were offered the remaining milk.All animals were vaccinated against foot and mouth disease, leptospirosis and rabies. Deworming was done at the beginning and end of the rainy period. The data analyzed correspond to the monthly test day milk and fat yields and fat content in lactations of Holstein-Gir cows from the four genetic groups cited above. Data were collected from January 1980 to December 1999 and edited in order to permit more consistency within the observations. In this way, 7,951 test day observations were used in the statistical analyses.

The dependent variables analyzed were milk yield (MY), fat yield (FY) and fat percentage (FP) obtained on the day of the test. The general statistical model used was $\mathrm{Y}_{\mathrm{ijklmno}}=\mu+$ year $_{\mathrm{i}}+$ month $_{\mathrm{j}}+\mathrm{gg}_{\mathrm{k}}+$ age $_{\mathrm{l}}+$ lacday $_{\mathrm{m}}+$ sire $_{\mathrm{n}}+$ $\operatorname{cow}_{\mathrm{ijklnmo}}+\mathrm{e}_{\mathrm{ijklmno}}$, where $\mathrm{Y}_{\mathrm{ijklmno}}$ is the dependent variable (MY, FY or FP), $\mu$ is a constant inherent to all observations, year $_{i}$ is the effect of the $i^{-{ }^{\text {th }}}$ year of calving with $i=1980, \ldots, 1999$, month $_{j}$ is the effect of $j^{\text {th }}$ month of calving, with $\mathrm{j}=1(\mathrm{Jan}), \ldots, 12(\mathrm{Dec}), \mathrm{gg}_{\mathrm{k}}$ is the effect of the $\mathrm{k}^{\text {th }}$ genetic group of the cow with $\mathrm{k}=1 / 2 \mathrm{H}, 1 / 4 \mathrm{H}, 5 / 8 \mathrm{H}$ and $5 / 8 \mathrm{Hinter} s e$, age $_{1}$ is the effect of the $1^{\text {th }}$ age of the cow at calving in months with $1=30$ to 190 , lacday $_{\mathrm{m}}$ is the effect of the $\mathrm{m}^{\text {th }}$ day of lactation of the cow with $\mathrm{m}=5$ to 330 in intervals of 5 days, sire $_{n}$ is the random effect of the $n^{\text {th }}$ sire with sire $\mathrm{n}_{\mathrm{n}} \sim \mathrm{N}\left(0, \mathrm{~s}_{\mathrm{s}}^{2}\right)$, cow $_{\mathrm{ijk} k \mathrm{mno}}$ is the random effect of the $\mathrm{o}^{\text {th }}$ cow born in the $\mathrm{i}^{\text {th }}$ month of the $\mathrm{k}^{\text {th }}$ genetic group of the $1^{\text {th }}$ age at calving progeny of the $n^{\text {th }}$ sire with $\operatorname{cow}_{i j k l n o} \sim \mathrm{N}(0$, $\left.\mathrm{s}_{\mathrm{v}}^{2}\right), \mathrm{e}_{\mathrm{ijklmno}}$ is the random effect of the $\mathrm{o}^{\text {th }}$ cow born in the $\mathrm{i}^{\text {th }}$ year of the $\mathrm{j}^{\text {th }}$ month of calving for the $\mathrm{k}^{\text {th }}$ genetic group of the $1^{\text {th }}$ age at calving in the $\mathrm{m}^{\text {th }}$ test day for progeny of the $\mathrm{n}^{\text {th }}$ sire with $\mathrm{e}_{\mathrm{ijklmno}} \sim \mathrm{N}(\mathrm{O}, \mathrm{R})$, and $\mathrm{R}$ is a variance-covariance matrix of the test-day observations with diagonal blocks in which each block corresponds to an observation per lactation per cow. Test-days within lactation of a cow were treated as repeated records. As might be expected due to the variable intervals between test-days the spatial power covariance structure provided the best fit for the repeated records (SAS Institute Inc, 1999; Cue, 2003). Relationships amongst animals were not included.

The estimates of fixed effects and variance and covariance were obtained by Restricted Maximum Likelihood (REML) analysis using an iterative process and a mixed model (Proc Mixed) (SAS Institute Inc, 2000; St-Pierre, 2001).

\section{Results and Discussion}

The most appropriate statistical model for analyzing the data of the three characteristics (MY, FY and FP), was the spatial power model. This was to be expected due to the improbability of the premise of equal covariance between test intervals.

Analysis of variance (F test) for the MY, FY and FP variables is shown in Table 1. With the exception of age of cow and FP all the variables produced a significant effect $(p<0.01)$ on the traits studied. Figure 1 shows the least squares means for year of calving for the MY, FY and FP traits. There was an initial decline in MY and FY until 1987 when the yield began to increase again, while FP showed a significant $(p<0,01)$ trend to decrease as the years passed. These variations are to be expected as probable consequences of feeding and management changes, as well as changes in the genetic composition of the herd over the years. A Brazilian study of lactation in Pitangueira cows (5/8 Red Poll and 3/8Guzerá) reported results similar to those found in our study (Lobo et al., 1984) and another

Table 1 - Summary of the variance analysis of fixed effects for milk yield (MY), fat yield (FY) and fat percentage (FP) of Holstein-Gir cows using the monthly test day data.

\begin{tabular}{lrrrr}
\hline Variables & df & \multicolumn{3}{c}{ Traits } \\
\cline { 3 - 5 } & & \multicolumn{1}{c}{ MY } & \multicolumn{1}{c}{ FY } & \multicolumn{1}{c}{ FP } \\
\hline Year of calving & 18 & $31.59^{* *}$ & $30.81^{* *}$ & $4.46^{* *}$ \\
Month of calving & 11 & $4.31^{* *}$ & $2.81^{* *}$ & $4.12^{* *}$ \\
Genetic group & 3 & $11.60^{* *}$ & $11.86^{* *}$ & $4.53^{* *}$ \\
Age of cow at calving & 32 & $4.71^{* *}$ & $4.46^{* *}$ & $0.62 \mathrm{~ns}$ \\
Days in lactation & 65 & $6.86^{* *}$ & $2.43^{* *}$ & $10.16^{* *}$ \\
\hline
\end{tabular}

$\mathrm{df}=$ degrees of freedom; $\mathrm{ns}=$ not significant at $\mathrm{p}>0.05$ by the $\mathrm{F}$ test **Significant at $\mathrm{p}<0.01$ by the $\mathrm{F}$ test. 

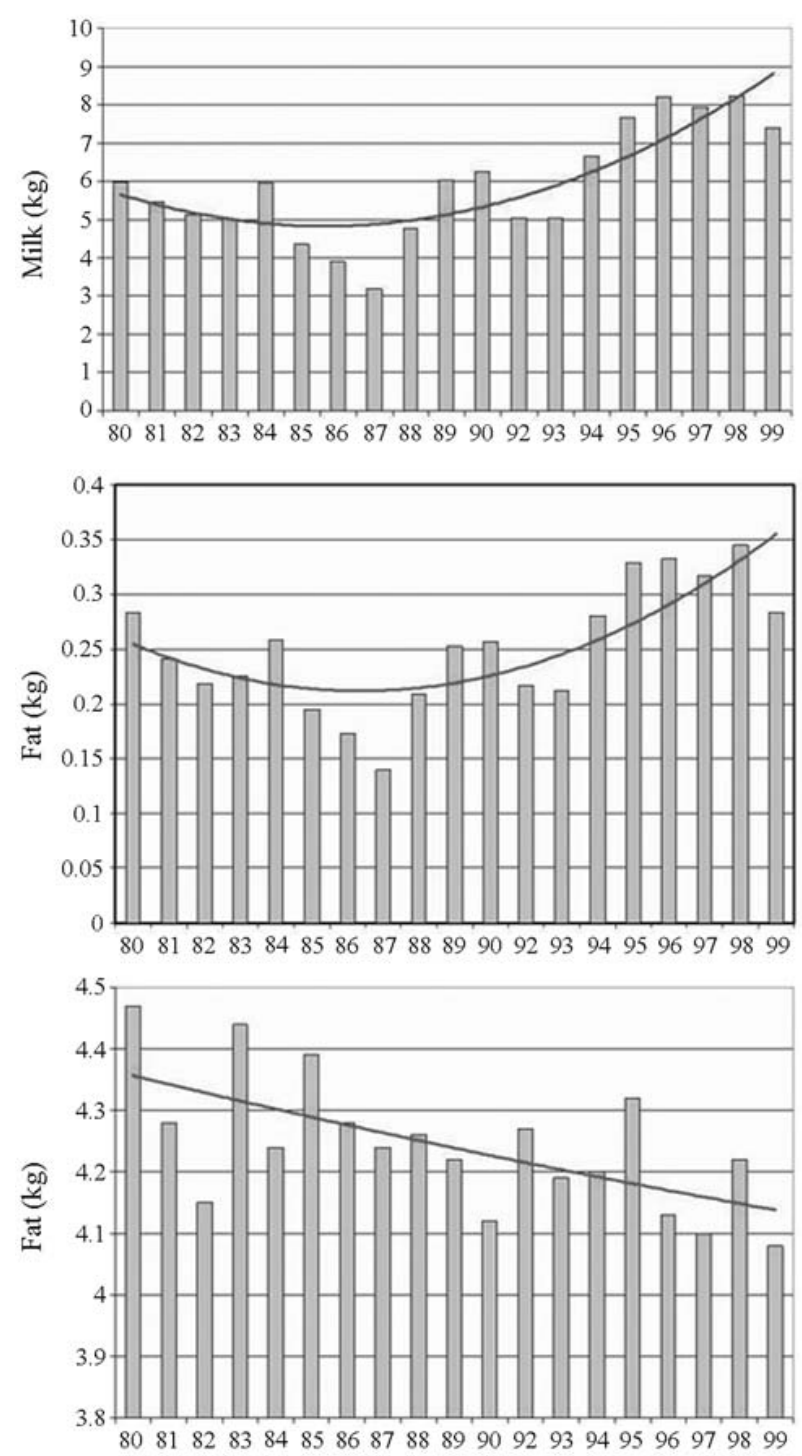

Figure 1 - Effects of year of calving on milk yield (MY), fat yield (FY) and fat percentage (FP) of crossbred Holstein-Zebu cows.

Brazilian study of lactation in 14 genetic groups of Holstein and Guzerá cattle reported a significant effect of year of calving on milk production (Martinez et al.,1988), although a study of lactations in crossbred Ayrshire, Holstein and Brown Swiss cows only detected a significant effect of year of calving on milk production (Rincón et al., 1982).

Days in lactation was an important source of variation $(\mathrm{p}<0.01)$ affecting MY, FY and FP (Table 1). Milk and fat production reached a peak after about 30 days lactation, followed by a slow decline throughout the remainder of the lactation period (Figure 2). Fat percent increased progressively as lactation advanced (Figure 2).

Table 2 shows the least squares means for MY, FY and FP for all the genetic groups analyzed and Figure 3 shows the effects of the different genetic groups on MY, FY and FP. The genetic group $1 / 2 \mathrm{H}$ presented the highest daily
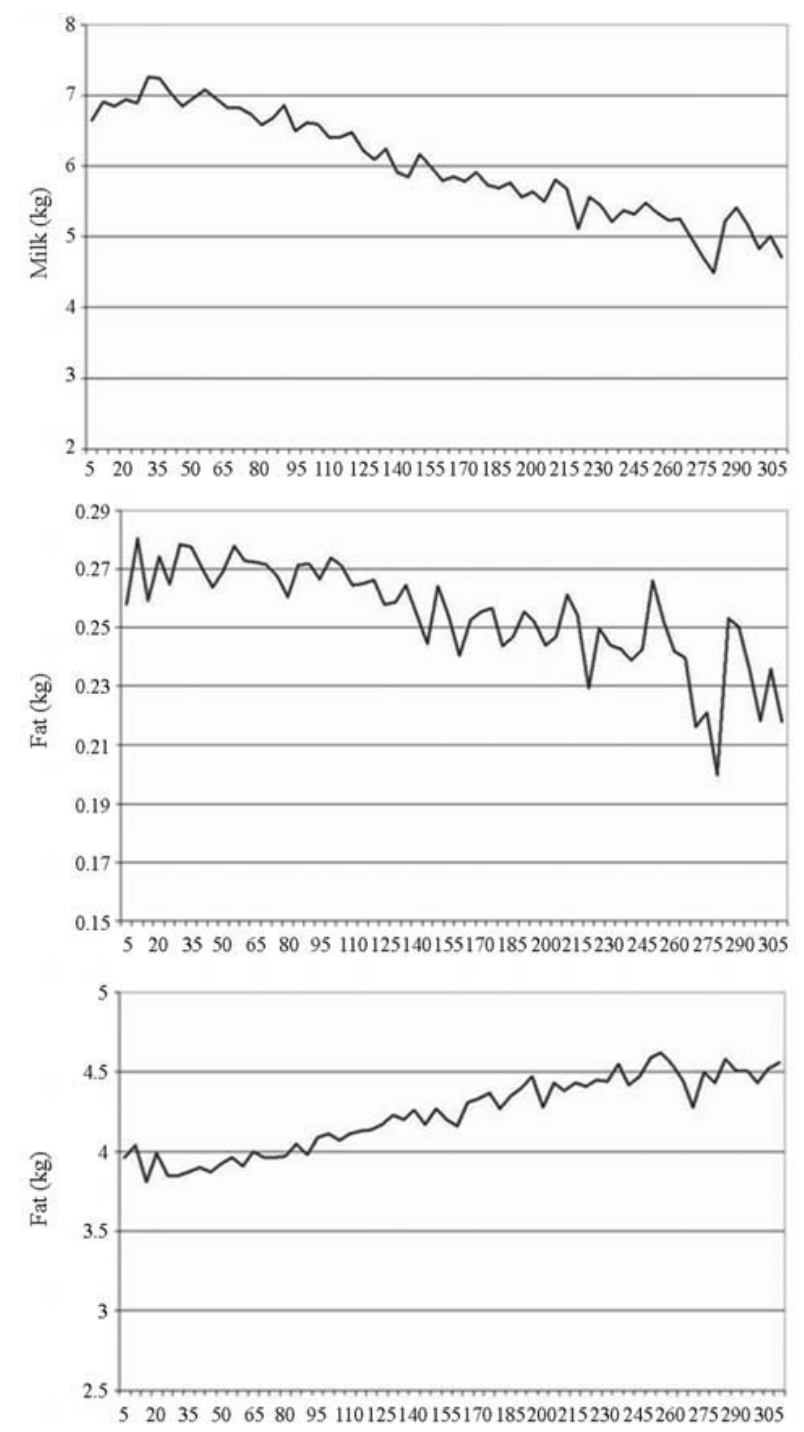

Figure 2 - Effects of days in lactation on milk yield (MY), fat yield (FY) and fat percentage (FP) of crossbred Holstein-Zebu cows.

averages for MY, FY and FP, so, as expected, the maximum heterosis occurred in this genetic group and was probably determined by non-additive genetic effects. This was true even for FP, which normally presents high estimates of heritability. This result is supported by the work of Madalena et al. (1990) who worked with lactations of crossbred Holstein-Guzerá cows, particularly in farms with a low level of management, and also by McDowell et al. (1996), who suggested that in hot climates the first crossbred generation, under optimum management and feeding conditions, can be used for dairy purposes. The next best MY and FY performance occurred in the $5 / 8 \mathrm{H}$ group, however, FP was low in this group, possibly due to the fact these cows were sired by Holstein bulls which normally sire offspring which produce lower levels of milk fat in comparison with offspring produced by Zebu sires. The $1 / 4 \mathrm{H}$ cows 
Table 2 - Least squares means of the four genetic Holstein-Gir crossbreed groups (1/2H, 1/4H, 5/8H, 5/8Hinter se) for milk yield (MY), fat yield (FY) and fat percentage (FP) based on monthly test day data.

\begin{tabular}{lllll}
\hline & \multicolumn{4}{c}{ Genetic group } \\
\cline { 2 - 5 } Variables & \multicolumn{1}{c}{$1 / 2 \mathrm{H}$} & $1 / 4 \mathrm{H}$ & \multicolumn{1}{c}{$5 / 8 \mathrm{H}$} & $5 / 8 \mathrm{H}$-inter se \\
\hline Milk yield $(\mathrm{kg})$ & $7.15 \pm 0.38$ & $5.24 \pm 0.38$ & $6.58 \pm 0.30$ & $4.68 \pm 0.37$ \\
Fat yield $(\mathrm{kg})$ & $0.313 \pm 0.015$ & $0.230 \pm 0.015$ & $0.267 \pm 0.012$ & $0.193 \pm 0.015$ \\
Fat percent $(\%)$ & $4.50 \pm 0.08$ & $4.31 \pm 0.08$ & $4.09 \pm 0.07$ & $4.07 \pm 0.08$ \\
\hline
\end{tabular}
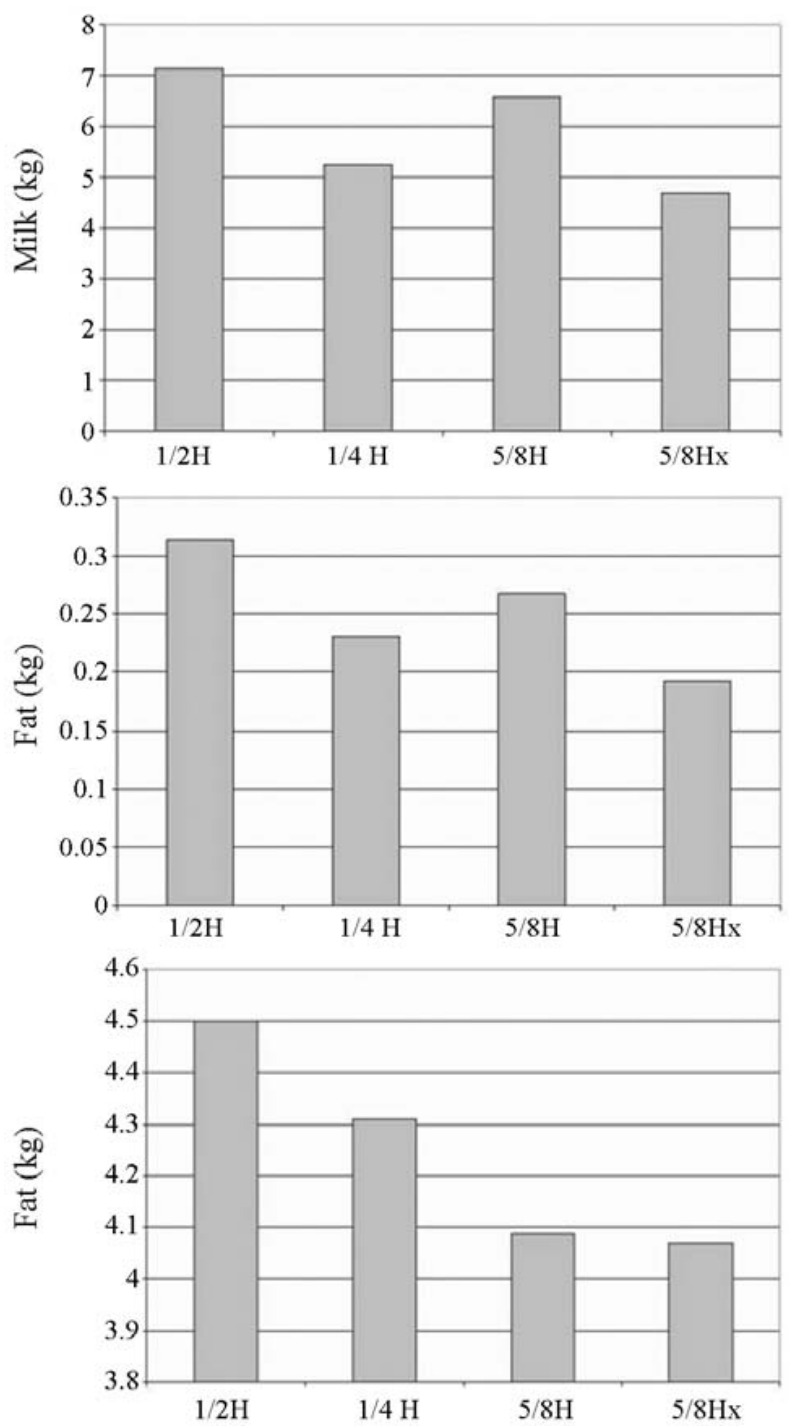

Figure 3 - Effects of genetic groups on milk yield (MY), fat yield (FY) and fat percentage (FP) of crossbred Holstein-Zebu cows.

presented lower values of milk and fat compared to $1 / 2 \mathrm{H}$ and $5 / 8 \mathrm{H}$ cows.

This was expected since, having on average $75 \%$ Zebu "blood", the crossbred cows are generally less productive. The cows from the $5 / 8$ Hinter se genetic group presented the lowest MY, FY and FP values of all the genetic groups analyzed. Recombination losses could explain the lower values of the $5 / 8$ synthetics compared with $5 / 8 \mathrm{H}$ cows. Lobo et al. (1984), working in Brazil with five generations of Pitangueira breed cows reported a significant advantage in MY of the $F_{1}$ generation in relation to the MY of other generations, although there were no important differences between the remaining generations. Syrstad (1989) produced a review which concluded that there was a reduction of approximately $24 \%$ in milk production in inter se crossbred cows, probably as a consequence of a reduction in heterozygosity from the $F_{1}$ to $F_{2}$ generations due to discontinuity in the combinations of the epistatic genetic effects. Madalena et al. (1990) also reported poor performance in inter se crossbred cattle but did not dismiss the possibility of looking for new "synthetic breeds", although they suggest that intense selection should be practiced to compensate for recombination losses. Thorpe et al. (1994) reported that the performance of inter se crossbred cattle was always worse than that of any other type of crossing and recommended that if crossbreeding is the basis of genetic improvement programs for dairy production in the tropics selection should be based on milk production per unit of metabolic weight, particularly in systems where the small farm is the basis of the dairy cattle industry. Pedersen and Christensen (1989), working with crossbred Red Danish, Finnish Ayrshire, Danish Friesian and Holstein Friesian cattle, concluded that the positive effects of heterosis reached in the $F_{1}$ generation were lost by the negative effects of recombination in the following generations. Madgwick and Goddard (1988), in Australia, reported that there were no recombination losses in milk and fat production since the last generations of crossbred cows demonstrated better performance than expected, although these authors did not work with inter se groups. Recombination losses in the $\mathrm{F}_{2}$ generation or in products derived from inter se breeding are a function of the fraction of recombination between the loci, differences in the genic frequencies and additive epistatic and dominance/dominance effects (Willham and Pollack, 1985).

Greater milk and fat yield (Figure 4) were observed in cows with an average age of 100 months (approximately 8.3 years), corresponding to the fourth or fifth lactation, while the highest fat percentage occurred in older cows with an average age of 190 months old. An age of 100 months is relatively old for specialized breeds, although 
when Zebu cows are the foundation this age is perfectly acceptable since, compared with European breeds, Zebu heifers usually reach puberty later in life with the first calving taking place after three years of age. Another factor that might explain this situation is that the curve and the lactation period in specialized cattle are already well-defined, while these same characteristics have not yet been established for Zebus. Therefore, the fact that the cows studied are products of crossbreeding with absorption of Gir genes might have contributed to this high average age of the cows at the highest level of production. Martinez et al. (1988) reported the highest milk production in crossbred HolsteinGuzerá cows at an average age of 96 months, while Lobo et al. (1984) found the highest production in Pitangueira cows between 104 and 105 months, corresponding approximately to their fifth lactation.
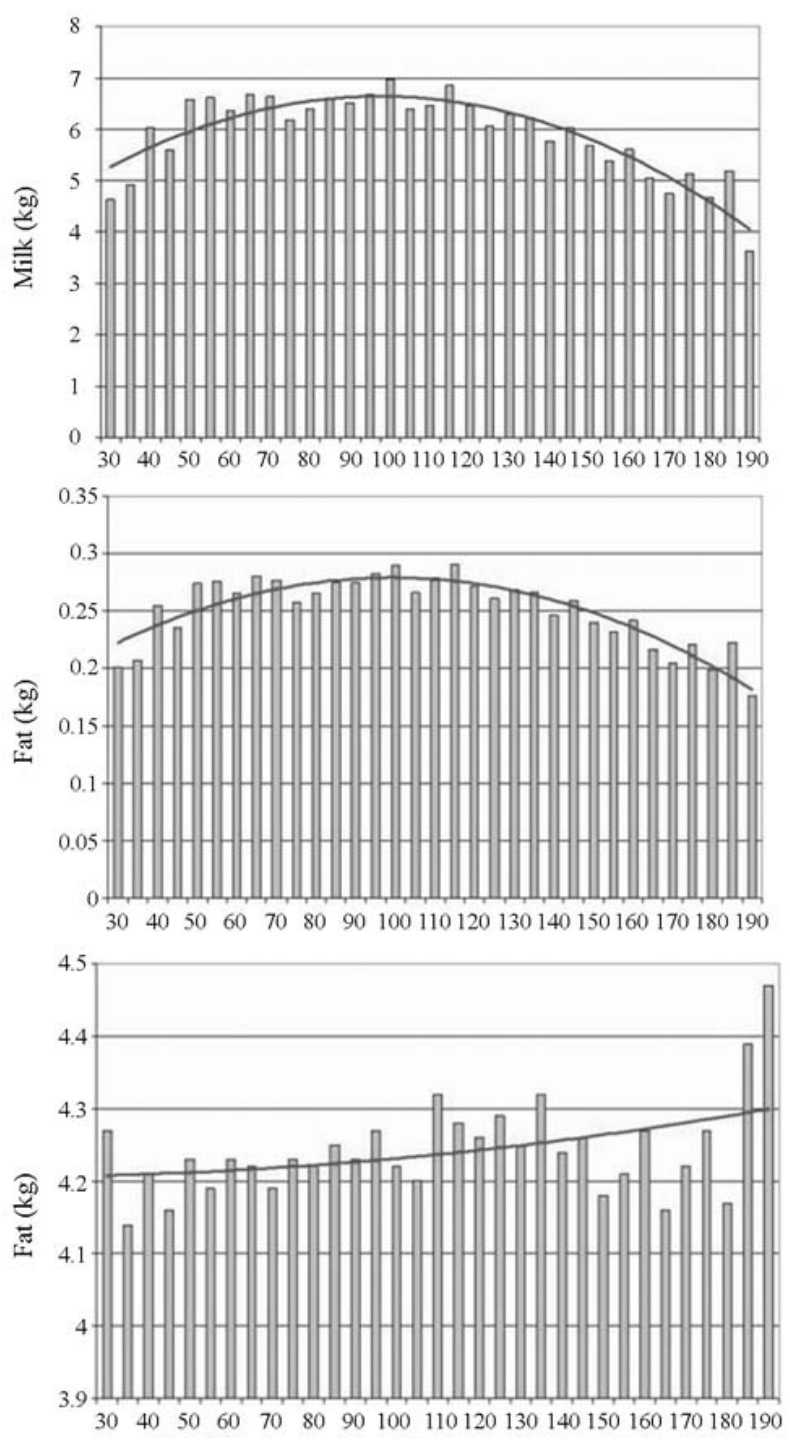

Figure 4 - Effects of age at calving (months) on milk yield (MY), fat yield (FY) and fat percentage (FP) of crossbred Holstein-Zebu cows.
The effect of month of calving is shown in Figure 5, from which it can be seen that the driest months (August to December) showed the highest milk and fat yields. In these months, the animals spent a good portion of time stabled and received feed supplements of spineless cactus and sorghum silage, as well as a commercial concentrate, depending on their level of production. Meanwhile, the highest FP values occurred in months with more rain in January to April, during which time the cattle depend exclusively on pasture grass which contains higher levels of fiber than the feed they receive in the dry season. Hence, this might have been one of the factors that contributed to the higher FP levels in the rainy season. In Australia, Madgwick and Goddard (1988) found higher fat production between January and July for the first and second lactations of pure or crossbred Holstein-Friesian, Jersey, Guernsey, Ayrshire and
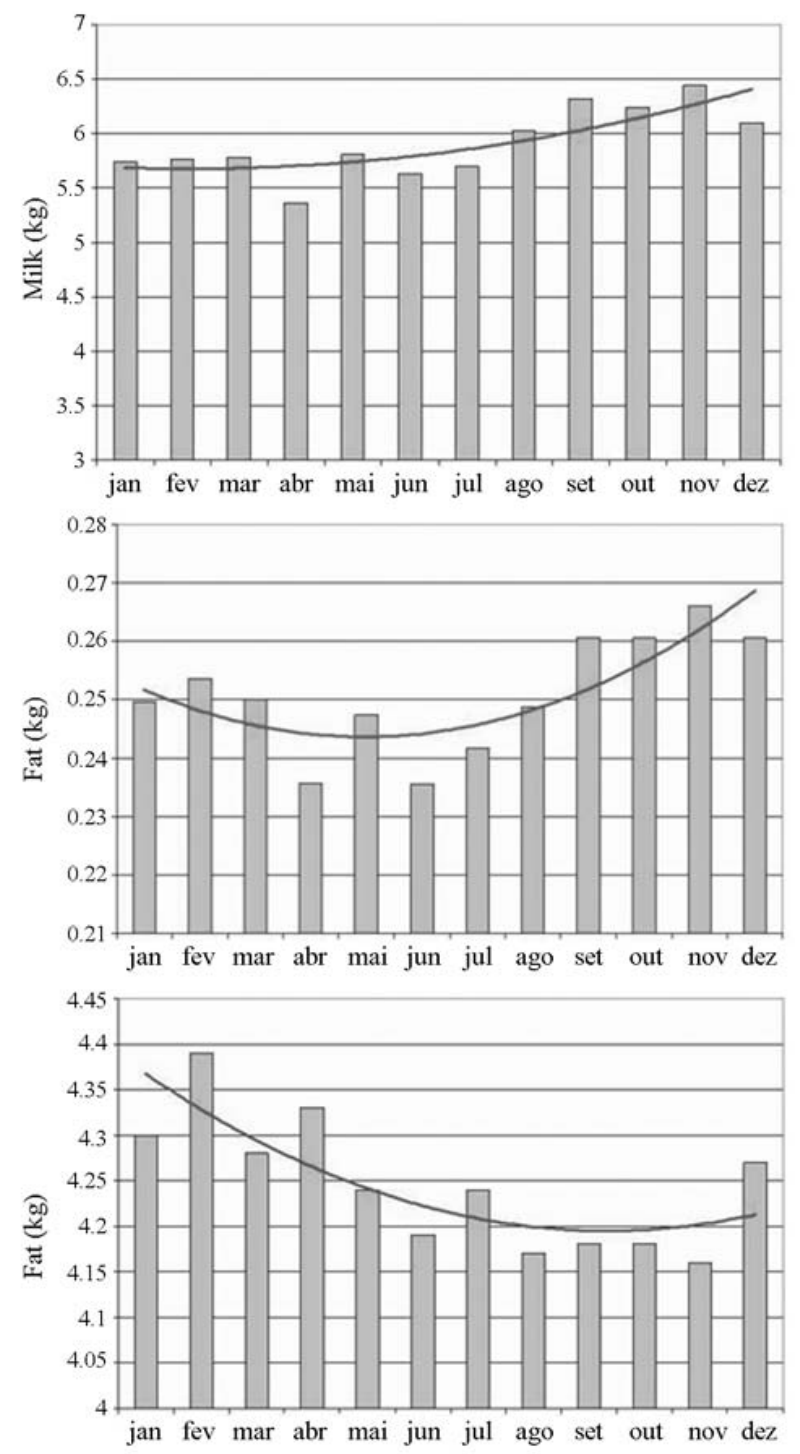

Figure 5 - Effects month of calving on milk yield (MY), fat yield (FY) and fat percentage (FP) of crossbred Holstein-Zebu cows. 
Australian Illawana Shorthorn breeds cows. Lobo et al. (1984) reported greater milk production in Brazil for Pitangueira cows that calved from July to December (Winter/Spring). When the months were grouped in two seasons lactations starting in the dry season showed greater yield, supporting our results. Martinez et al. (1988), also working in Brazil, found a significant month of calving effect on yield in crossbred Holstein-Guzerá cows, while Rincón et al. (1982), working with lactations in crossbred Ayrshire, Holstein and Brown Swiss cows, observed lower milk and fat production in cows that gave birth from July to September.

The covariance estimates for MY, FY and FP according to days in lactation (grouped in five day intervals) are presented in Table 3, from which it can be seen that the lowest covariance level was for FP (0.9652) while MY presented the highest value $(0.9838)$.

In general, these covariance estimates between repeated measurements of one animal, were high, showing a strict association between observations in the interval between days studied. The phenotypic correlation slightly decreased for each additional day in the interval between observations. Similar results were observed by Norman et al. (1999) who analyzed bovine lactations in the USA and Canada under the autoregressive structure [ar(1)].

Several conclusions can be drawn from this research. The $1 / 2 \mathrm{HG}$ genetic group presented the best productive performance regardless of the trait analyzed. The performance of the $5 / 8 \mathrm{H}$ genetic group showed promise but intense selection is needed in these animals because they are the genetic foundation for the formation of the synthetic breed. The $5 / 8 \mathrm{H}$ (inter se) genetic group showed lower performance compared to the other groups and it is necessary to review the formation of this genetic group and subject it to rigorous evaluation and selection programs and evaluate the possibility of using other breeds as a foundation of the system. The fixed factors evaluated were important sources of variation effecting MY, FY and FP so these factors should be considered in the evaluation of the productive performance of crossbred cows. The production averages indicate that for practical and economic considerations cows between eight and nine years old should be discarded when production begins to decrease.

Table 3 - Covariance estimates of the random effects for milk yield (MY), fat yield (FY) and fat percentage (FP) for Holstein-Gir cows based on monthly test day data.

\begin{tabular}{lcll}
\hline Parameters & MY & FY & FP \\
\hline Sire & 0.5704 & 0.000926 & 0.02667 \\
Cow sp (pow)* & 0.9838 & 0.9788 & 0.9652 \\
Residual & 4.4463 & 0.008588 & 0.3526 \\
\hline
\end{tabular}

*Spatial power model

\section{Acknowledgments}

The authors acknowledge the Empresa Pernambucana de Pesquisa Agropecuária (IPA) for making available the data for this study. The valuable statistical advice of Dr. Roger Cue from the Dept. of Animal Science of McGill University is also acknowledged.

\section{References}

Ahlborn-Breier G and Honenboken WD (1991) Additive and nonadditive genetic effects on milk production in dairy cattle: Evidence for major individual heterosis. J Dairy Sci 74:592-602.

Cue RI (2003) Repeated measurements. http://animsci.agrenv. mcgill.ca/servers/anbreed/statisticsII/ (july 14, 2007).

IBGE (2004) Produção da Pecuária Municipal 32:1-35.

Lobo RB, Duarte FAM, Gonçalves AAM, Oliveira JA and Wilcox CJ (1984) Genetic and environmental effects on milk yield of Pitangueiras cattle. Anim Prod 39:157-163.

Madalena FH, Lemos AM, Teodoro RL, Barbosa RT and Monteiro JBN (1990) Dairy production and reproduction in Holstein-Friesian and Guzerá crosses. J Dairy Sci 73:18721886.

Madgwick PA and Goddard ME (1989) Comparison of purebred and crossbred dairy cattle for Victoria: Estimation of genetic effects for yield. Austral J Exp Agric 29:1-7.

Martinez ML, Lee AJ and Lin CY (1988) Age and Zebu-Holstein additive and heterotic effects on lactation performance and reproduction in Brazil. J. Dairy Sci 71:800-808.

McDowell RE, Wilk JC and Talbott CW (1996) Economic viability of crosses of Bos taurus and Bos indicus for dairying in warm climates. J Dairy Sci 79:1292-1303.

Norman HD, Vanraden PM, Wright JR and Smith LA (1999) Mathematical representations of correlations among yield traits and somatic cell score on test day. J Dairy Sci 82:2205-2211.

Pedersen J and Christensen LG (1989) Heterosis for milk production traits by crossing Red Danish, Finnish Ayrshire and Holstein-Friesian cattle. Livest Prod Sci 23:253-266.

Rincón EJ, Scrermerhorn EC, McDowell RE and McDaniel BT (1982). Estimation of genetic effects on milk yield and constituent traits in crossbred dairy cattle. J. Dairy Sci 65:848856.

SAS Institute Inc (1999) Repeated Statement. Cary, NC.

SAS Institute Inc (2000) SAS Companion for the Microsoft Windows Environment, v. 8. Cary, NC, 542 pp.

Simpson JR and Conrad JH (1993) Intensification of cattle production systems in Central America: Why and when. J Dairy Sci 76:1744-1752.

Swan AA and Kinghorn BP (1992) Evaluation and exploitation of crossbreeding in dairy cattle. J Dairy Sci 75:624-639.

Syrstad O (1989) Dairy cattle cross-breeding in the tropics: Performance of secondary cross-bred populations. Livest Prod Sci 23:97-106.

St-Pierre NR (2001) Integrating quantitative findings from multiple studies using mixed model methodology. J Dairy Sci 84741-755.

Thorpe W, Morris CA and Kangethe P (1994) Crossbreeding of Ayrshire, Brown Swiss, and Sahiwal cattle for annual and 
lifetime milk yield in the lowland tropics of Kenya. J Dairy Sci 77:2415-2427.

Touchberry RW (1992) Crossbreeding effects in dairy cattle: The Illinois experiment, 1949 to 1969. J Dairy Sci 75:640-667.

Willham RL and Pollack E (1985) Theory of heterosis. J Dairy Sci 68:2411-2417.
Zarnecki A, Norman HD and Gierdziewicz M (1993) Heterosis for growth and yields traits from crosses of Friesian strains. J Dairy Sci 76:1661-1670.

Associate Editor: Pedro Franklin Barbosa

License information: This is an open-access article distributed under the terms of the Creative Commons Attribution License, which permits unrestricted use, distribution, and reproduction in any medium, provided the original work is properly cited. 